\title{
Performa dan Karkas Kelinci Jantan Lokal (Lepus nigricollis) yang diberi Ransum Megandung Limbah Wine Anggur Terfermentasi
}

\author{
I Gede Mahardhika-Atmaja ${ }^{1}$, Andi Baso Kresna ${ }^{2}$ \\ 1)Balai Besar Pelatihan Pertanian Batangkaluku, Jl. Malino KM.3. Kabupaten Gowa \\ 2) Widyaiswara Balai Besar Pelatihan Pertanian Batangkaluku, Jl. Malino KM.3. Kabupaten Gowa \\ e-mail : ${ }^{1)}$ mahardhikaatmaja@gmail.com
}

\begin{abstract}
This research was conducted in Tejakula Village, Buleleng, Bali. Randomized Block Design was utilized with five treatment rations and four weight groups so there were 20 experimental units. Rabbit samples were randomly allocated into five treatments, namely rabbits that received treatment $P 0$ : rations without adding fermented and non-fermented wine waste (control ration); P1 rations with adding 5\% fermented wine waste; P2: rations with adding $10 \%$ fermented wine waste; P3: rations with $5 \%$ non-fermented wine waste and P4: rations with adding $10 \%$ non-fermented wine waste. Meanwhile, rations and dringking water were given on an ad libitum basis. The study found that the local male rabbit performance given rations with additional fermented and non-fermented grape wine waste to level off $10 \%$ (P1, P2, P3 and P4) showed higher results than the conrol ration treatment $(P 0)$. The carcass variable also resulted the same thing (P1, P2, P3 and P4) which producing higher carcasses than the control ration $(P O)$. The study concluded that performance and local male carcasses showed no difference.
\end{abstract}

Keywords: grape wine waste, fermentation, performance, carcass

\begin{abstract}
Abstrak
Penelitian ini dilakukan di Desa Tejakula, Buleleng. Rancangan yang digunakan dalam penelitian ini adalah Rancangan Acak Kelompok, dengan lima perlakuan ransum dan empat kelompok berat badan sehingga terdapat 20 unit percobaan. Kelinci-kelinci dialokasikan secara acak kedalam lima perlakuan, yaitu kelinci-kelinci yang mendapat Perlakuan $\mathrm{P}_{0}$ : Ransum tidak menggunakan limbah wine anggur terfermentasi dan non fermentasi (Ransum Kontrol), $\mathrm{P}_{1}$ : menggunakan $5 \%$ limbah wine anggur terfermentasi, $\mathrm{P}_{2}$ : menggunakan $10 \%$ limbah wine anggur terfermentasi, $P_{3}$ : menggunakan $5 \%$ limbah wine anggur non fermentasi dan $\mathrm{P}_{4}$ : menggunakan $10 \%$ limbah wine anggur non fermentasi. Ransum dan air minum diberikan secara ad_libitum. Berdasarkan hasil penelitian didapatkan bahwa performa kelinci jantan lokal yang diberikan ransum dengan tambahan limbah wine anggur terfermentasi dan non terfermentasi sampai level $10 \% \quad\left(P_{1}, P_{2}, P_{3}\right.$ dan $\left.\mathrm{P}_{4}\right)$ menunjukan hasil yang lebih tinggi dari perlakuan ransum kontrol $\left(P_{0}\right)$. Variabel karkas juga menunjukan hal yang sama yaitu $\left(\mathrm{P}_{1}, \mathrm{P}_{2}, \mathrm{P}_{3}\right.$ dan $\left.\mathrm{P}_{4}\right)$ menghasilkan karkas lebih tinggi dari pada ransum kontrol $\left(\mathrm{P}_{0}\right)$. Hasil penelitian dapat disimpulkan bahwa performa dan karkas kelinci jantan lokal tidak menunjukan perbedaan.
\end{abstract}

Kata Kunci: Limbah wine anggur, fermentasi, performa, karkas 


\section{PENDAHULUAN}

Kelinci sebagai salah satu komoditas ternak mudah berkembangbiak, tidak banyak membutuhkan modal dan tidak memerlukan lahan yang luas serta sebagai hewan kesayangan sehingga kelinci perlu dikembangkan. Pengembangan ternak ruminansia di Bali mengalami kendala utama adalah lahan, dimana lahan semakin sempit dan tingkat reproduksinya lambat. Sedangkan ternak unggas dan babi membutuhkan pakan yang mahal dan berkompetitif dengan manusia (Suradi. 2005). Salah satu solusi untuk memenuhi kebutuhan protein hewani masyrakat adalah pengembangan ternak kelinci.

Perkembangan kelinci saat ini di Bali khususnya sebagai ternak pengahasil daging masih kurang memuaskan, hal dikarenakan pengetahuan peternak dalam pemberian pakan kelinci belum memperhitungkan kebutuhan nutrien minimal dan belum memperhatikan status fisiologi ternak. Peternak hanya memberikan pakan berupa hijauan, limbah sayur, limbah pertanian dan sedikit peternak yang memberikan tambahan dedak dalam pakannya sehingga sering ditemukan kelinci pada saat melahirkan memakan anaknya sendiri (kanibal) akibat kekurangan nutrien. Pemberian pakan lengkap (feed complete) untuk ternak kelinci akan memberikan tambahan bobot badan yang lebih tinggi dibandingkan pakan hijauan, hal ini sejalan dengan penelitian yang dilakukan Raharjo (2005) melaporkan bahwa kelinci Rex yang diberi rumput lapang ad libitum (100\%) pertambahan bobot badannya hanya sebesar $610 \mathrm{~g} /$ ekor dalam 12 minggu dan pemberian rumput lapang $+60 \mathrm{~g}$ konsentrat pertambahan bobot badannya sebesar $1.191 \mathrm{~g} /$ ekor dalam waktu yang sama. Namun, Pemberian pakan lengkap terhadap ternak kelinci akan terkendala oleh harga bahan pakan yang semakin meningkat setiap tahunnya, sehingga akan menyulitkan peternak kelinci yang sebagian besar dalam menjalankan usahanya masih bersifat tradisional.

Mastika (1991) melaporkan salah satu alternatif untuk penyediaan pakan yang murah dan kompetitif adalah melalui pemanfaatan limbah, baik limbah pertanian, peternakan maupun limbah industri pertanian. Kabupaten Buleleng merupakan sentra penghasil anggur di Bali dari total produksi buah anggur pada tahun 2013 yaitu 9,118 ton buah anggur segar, 50\% diantaranya masuk ke industri pengolahan wine (BPS Buleleng 2013). Limbah industri pembuatan wine berbahan anggur yang memiliki kandungan nutrien yang cukup bagi ternak, harganya murah dan tersedia secara kontinyu dalam upaya untuk menurunkan biaya produksi.

Limbah industri pembuatan wine dari anggur mempunyai potensi yang cukup besar untuk dimanfaatkan sebagai pakan ternak karena produksinya tinggi. Pengolahan anggur menjadi wine akan mengasilkan limbah berupa biji dan kulit sebesar $40 \%$. Berdasarkan pengamatan yang dilakukan Voisinet et al. (1997) penggunaan ransum dengan tambahan limbah cair wine dari anggur akan menghasilkan perubahan kimia pada daging menjadi lebih empuk. Berdasarkan penelitian Moote (2012) penggunaan limbah wine anggur sebesar $7 \%$ dalam ransum sapi angus jantan tidak menunjukan perbedaan yang nyata dari segi pertambahan bobot badan serta skor warna daging dibandingkan kontrol. 
Penelitian ini bertujuan untuk mengetahui potensi limbah wine dari anggur terfermentasi sebagai pakan kelinci dapat meningkatkan performans dan karkas kelinci jantan lokal.

\section{METODE}

\subsection{Kelinci}

Kelinci yang digunakan dalam penelitian ini adalah kelinci jantan lokal dengan rata-rata bobot badan $491,6 \mathrm{gr} \pm 76,3 \mathrm{gr}$ yang dilakukan di Desa Tejakula, Buleleng.

\subsection{Kandang}

Kandang yang digunakan adalah kandang tunggal berukuran panjang $50 \mathrm{~cm}$, lebar $50 \mathrm{~cm}$, tinggi $45 \mathrm{~cm}$ dan berbentuk panggung dengan ketinggian $50 \mathrm{~cm}$ di atas permukaan tanah (Nuriyasa, 2012).

\subsection{Ransum dan Air Minum}

Ransum yang digunakan dalam penelitian ini diberikan pada ternak dalam bentuk pelet dengan kandungan protein kasar $16 \%$ dan energi termetabolis $2.500 \mathrm{kkal} / \mathrm{kg}$ (NRC, 2001), terdiri dari 5 jenis formula ransum sesuai dengan perlakuan. Pemberian ransum dan air minum dilakukan dua kali sehari yaitu pada pagi dan sore hari yang diberikan secara ad libitum.

\subsection{Peformans}

Variabel peformans yang diamati dalam penelitian ini meliputi: bobot badan akhir, pertambahan bobot badan harian, konsumsi ransum dan konversi ransum. Bobot badan akhir didapatkan dari penimbangan bobot kelinci pada akhir penelitian.

\subsection{Karkas}

Data karkas diperoleh dengan cara memotong ternak kelinci pada akhir penelitian. Pemotongan ternak kelinci dengan memotong vena jugularis pada leher untuk mengeluarkan darahnya (Alhaidary, et al., 2010). Persentase karkas dihitung sebagai berat karkas segar dibagi dengan berat tubuh sebelum dipotong dikalikan 100 (Lukefahr et al., 1981). Pemotongan karkas untuk pemasaran komersial, karkas dipotong-potong menjadi 2 potongan kaki belakang kiri dan kanan, 1 potongan pinggang dan punggung, 2 potongan dada dan leher serta 2 potongan kaki depan kiri dan kanan (Sartika dan Raharjo, 1991).

\subsection{Rancangan Percobaan dan Analisis Statistik}

Rancangan percobaan yang digunakan dalam penelitian ini adalah Rancangan Acak Kelompok (RAK) yang terdiri dari lima perlakuan dan empat blok atau kelompok bobot badan sebagai ulangan sehingga terdapat 20 unit percobaan. Kelima perlakuan tersebut adalah: Perlakuan $\mathrm{P}_{0}$ : Ransum tidak menggunakan limbah wine anggur terfermentasi dan non fermentasi (Ransum Kontrol). Perlakuan $\mathrm{P}_{1}$ : Ransum menggunakan $5 \%$ limbah wine anggur terfermentasi. Perlakuan $\mathrm{P}_{2}$ : Ransum menggunakan $10 \%$ limbah wine anggur terfermentasi. perlakuan $\mathrm{P}_{3}$ : Ransum menggunakan $5 \%$ limbah wine anggur non fermentasi. Perlakuan $\mathrm{P}_{4}$ : Ransum menggunakan $10 \%$ limbah wine anggur non fermentasi. Data yang diperoleh dianalisa dengan Sidik Ragam, apabila diantara perlakuan terdapat perbedaan yang nyata $(\mathrm{P}<0.05)$, maka analisa dilanjutkan dengan $\mathrm{Uji}$ Jarak Berganda Duncan dengan tingkat signifikan 5\% (Steel dan Torrie,1991)

\section{HASIL DAN PEMBAHASAN}

Hasil penelitian menunjukan bahwa perlakuan ransum mengunakan limbah wine 
anggur terfermentasi tidak menyebabkan perbedaan yang nyata $(P>0,05)$ terhadap konsumsi ransum harian, pertambahan bobot badan harian, dan konversi ransum (Tabel 1). Bobot badan akhir kelinci jantan lokal yang yang diberikan ransum perlakuan $\mathrm{P}_{4}$ adalah $1.750,0 \mathrm{gr}$ yang paling tinggi dan secara statistik berbeda nyata $(P<0,05)$ dengan perlakuan ransum $\mathrm{P}_{0}$ (kontrol). Bobot badan akhir dipengaruhi oleh jumlah pakan yang dikonsumsi dan nutrien yang diserap dalam tubuh kelinci. Nutrien yang diserap lebih banyak oleh ternak kelinci akan memberikan bobot badan akhir lebih tinggi, hal ini disebabkan karena perkembangan jaringanjaringan tubuh ternak dan deposit lemak akan banyak dilakukan oleh tubuh ternak (McNitt et al., 1996).

Penggunaan limbah wine terfermentasi dan non fermentasi sampai $10 \%$ dalam ransum tidak mengubah kandungan energi dan protein dalam ransum sehingga konsumsi pakan berbeda tidak nyata. Berdasarkan penelitian Moote (2012) penggunaan limbah wine anggur cair sebesar $7 \%$ dalam ransum sapi angus jantan tidak menunjukan perbedaan yang nyata dari segi pertambahan bobot badan dibandingkan kontrol. Hasil ini sejalan dengan penelitiaan sebelumnya bahwa Penggunaan limbah wine sebagai pakan tidak mampu memenuhi kebutuhan energi untuk menopang pertumbuhan serta produksi susu ternak ruminansia, apabila penggunaannya dalam bentuk pakan tunggal (Abarghuei et al., 2010). Rataan konsumsi pakan dipengaruhi oleh energi yang terdapat dalam pakan. Semakin tinggi energi yang terdapat dalam pakan maka semakin rendah konsumsi dan sebaliknya semakin kecil energi yang terdapat dalam pakan maka semakin tinggi konsumsi. Apabila kandungan energi yang terdapat dalam masing - masing perlakuan sama maka konsumsi pakan kelinci tersebut juga sama. Menurut Parakkasi (1999), tingkat konsumsi dipengaruhi oleh beberapa faktor antara lain bobot badan, jenis kelamin, umur, bangsa ternak, dan kualitas nutrien pakan terutama kandungan energi dan protein kasar. Sejalan dengan hal tersebut, Hartadi. et al. (2008) menyatakan bahwa kandungan energi dalam pakan akan berbanding terbalik dengan konsumsi pakan. Hasil penelitian terhadap pertambahan bobot badan harian kelinci jantan lokal menunjukan bahwa perlakuan ransum $\mathrm{P}_{4} \quad$ (17,1 gr/hari) paling tinggi yang tidak berbeda nyata $(P>0,05)$ dengan perlakuan ransum $P_{0}, P_{1}, P_{2}$ dan $P_{3}$. Hal ini berarti penggunaan limbah wine terfermentasi dan non fermentasi sampai $10 \%$ dalam ransum tidak memberikan pengaruh terhadap pertambahan bobot badan harian kelinci. Penggunaan limbah wine terfermentasi dan non fermentasi dalam ransum kelinci memberikan konsumsi pakan yang relatif sama, sehingga pertambahan bobot badan harian kelinci berbeda tidak nyata. Seperti yang diungkapkan Soeparno (2005) konsumsi bahan kering dan kandungan nutrien pakan mempunyai pengaruh yang besar terhadap pertambahan bobot badan ternak, sehingga apabila konsumsi bahan kering dan kandungan nutrien pakan antar kelompok perlakuan tidak menunjukkan perbedaan yang nyata, maka dimungkinkan pertambahan bobot badan tidak menunjukkan perbedaan yang nyata pula. 
kelompok perlakuan tidak menunjukkan perbedaan yang nyata, maka dimungkinkan pertambahan bobot badan tidak menunjukkan perbedaan yang nyata pula.

Konsumsi ransum dan pertambahan bobot badan harian tidak berbeda nyata menyebabkan konversi ransum kelinci jantan lokal yang diberikan ransum dengan tambahan limbah wine terfermentasi dan non fermentasi sampai $10 \%$ juga tidak berbeda nyata $(P>0,05)$ pada kelima perlakuan ransum. Hal ini sesuai dengan pendapat Basuki (2002) yang menyatakan bahwa faktor yang mempengaruhi konversi pakan adalah konsumsi pakan dan pertambahan bobot badan. Dari hasil penelitian menunjukan bahwa perlakuan ransum $\mathrm{P}_{4}$ menunjukan efisiensi pengunaan ransum paling tinggi yang diindikasikan dengan angka konversi ransum paling rendah yaitu 2,66. Menurut Rasyaf pegangan berproduksi karena melibatkan bobot badan dan konsumsi pakan. Siregar (1994) menambahkan bahwa konversi pakan digunakan sebagai tolok ukur efisiensi produksi. Semakin kecil nilai konversi pakan, maka semakin efisien seekor ternak dalam menggunakan pakan, yang berarti semakin sedikit jumlah pakan yang dibutuhkan untuk mencapai pertambahan satu satuan bobot badan.

Hasil penelitian terhadap karakteristik karkas kelinci jantan lokal yang diberikan ransum dengan tambahan limbah wine anggur terfermentasi secara umum tidak menunjukan perbedaan nyata $(P>0,05)$ yang meliputi rataan persentase karkas, rataan persentase potongan komersial karkas, rataan komposisi fisik karkas, dan meat bone ratio (MBR). diberikan sehingga dapat menghasilkan berat potong yang maksimal. Kondisi tersebut

Tabel 1. Peformans Kelinci Jantan Lokal yang Diberikan Ransum dengan Tambahan Limbah Wine Anggur Terfermentasi

\begin{tabular}{|c|c|c|c|c|c|c|}
\hline \multirow{2}{*}{ Variabel } & \multicolumn{5}{|c|}{ Perlakuan } & \multirow{2}{*}{ SEM } \\
\hline & $\mathrm{P}_{0}$ & $P_{1}$ & $\mathrm{P}_{2}$ & $\mathrm{P}_{3}$ & $\mathrm{P}_{4}$ & \\
\hline Bobot Badan Akhir (gr) & $1.561,0^{\mathrm{b}}$ & $1.630,0^{\mathrm{ab}}$ & $1.730,0^{\mathrm{a}}$ & $1.662,0^{\mathrm{ab}}$ & $1.750,0^{\mathrm{a}}$ & 47,9 \\
\hline Konsumsi Ransum (gr/hari) & $54,6^{a}$ & $55,0^{a}$ & $56,0^{\mathrm{a}}$ & $56,7^{a}$ & $57,5^{a}$ & 1,15 \\
\hline $\begin{array}{l}\text { Pertambahan Bobot Badan } \\
\text { Harian (gr/Hari) }\end{array}$ & $14,70^{\mathrm{a}}$ & $15,43^{a}$ & $15,85^{a}$ & $16,95^{\mathrm{a}}$ & $17,10^{\mathrm{a}}$ & 1,89 \\
\hline Konversi Ransum & $3,04^{a}$ & $2,95^{a}$ & $2,71^{a}$ & $2,85^{a}$ & $2,66^{a}$ & 0,23 \\
\hline \multicolumn{7}{|c|}{$\begin{array}{l}\text { Keterangan: } \\
\text { 1. } \mathrm{P}_{0}: \text { Ransum tidak menggunakan limbah wine anggur terfermentasi dan non fermentasi (Ransum Kontrol), } P_{1} \\
\text { dan } \mathrm{P}_{2}: \text { Ransum menggunakan } 5 \text { dan } 10 \% \text { limbah wine anggur terfermentasi serta } \mathrm{P}_{3} \text { dan } \mathrm{P}_{4}: \text { Ransum } \\
\text { menggunakan } 5 \text { dan } 10 \% \text { limbah wine anggur non fermentasi. } \\
\text { 2. Superskrip yang sama pada baris yang sama menunjukan perbedaan yang tidak nyata }(P>0,05) \text { dan superskrip } \\
\text { berbeda pada baris yang sama menunjukan perbedaan yang nyata }(P<0,05) \\
\text { 3. SEM : Standard Error Of The Treatment Means }\end{array}$} \\
\hline
\end{tabular}

Perlakuan ransum $\mathrm{P}_{2}$ dan $\mathrm{P}_{4}$ menghasilkan bobot potong yang berbeda nyata $(P<0,05)$ (Tabel 2) dengan perlakuan ransum $\mathrm{P}_{0}$ (kontrol). Bobot potong sangat berhubungan erat dengan pertumbuhan. Pertumbuhan sangat ditentukan oleh faktor pakan yang (1996), konversi pakan digunakan sebagai sangat berpengaruh langsung terhadap berat karkas dan persentase karkas.

Dari hasil penelitian menunjukan bobot potong perlakuan ransum $\mathrm{P}_{4}$ mempunyai rataan bobot potong paling tinggi (1.747,5 gr), secara statistik berbeda nyata $(P<0,05)$ dengan perlakuan kontrol. Hal ini dikarenakan 
perlakuan ransum $P_{0}$ memiliki kandungan serat kasar yang paling tinggi. Jenis pakan,

komposisi kimia dan konsumsi pakan berpengaruh besar terhadap pertumbuhan. Pada ransum iso energi dan iso protein, maka makin tinggi konsumsi ransum akan diikuti dengan peningkatan konsumsi energi dan protein. Konsumsi protein dan energi yang lebih tinggi akan menghasilkan laju pertumbuhan yang lebih cepat (Soeparno, 2005).

Persentase karkas paling tinggi dihasilkan oleh kelinci yang diberikan perlakuan ransum $\mathrm{P}_{4}$ adalah $47,77 \%$, yang secara statistik tidak menunjukan perbedaan yang nyata $(P>0,05)$. Hasil penelitian ini sejalan dengan penelitian Moote (2012) penggunaan limbah wine anggur cair sebesar $7 \%$ dalam ransum sapi angus jantan tidak menunjukan perbedaan yang nyata dari segi bobot karkas panas yang dihasilkan. Produksi karkas tercermin dari komponen daging, lemak, dan tulang kelinci yang sangat dipengaruhi oleh berat potongnya (Bram

Brahmantiyo dan Raharjo, 2009). Hasil penelitian ini tidak jauh berbeda dengan penelitian Nuriyasa (2012) yang memperoleh persentase karkas kelinci lokal yang dipelihara selama 84 hari yang dipotong pada bobot potong dan umur yang sama tidak berbeda adalah $45,82 \%$.

Tidak terjadi perbedaan yang nyata pada semua perlakuan terhadap variabel potongan komersial karkas kelinci jantan lokal yang diberikan ransum dengan tambahan limbah wine terfermentasi sampai level 10\% (Tabel 2). Hasil penelitian mendapatkan rataan persentase kaki depan, kaki belakang, pinggang dan punggung, dan dada-leher masing-masing 16,82\%; 30,75\%; 23,18\% dan
$30,35 \%$. Hasil penelitian ini sejalan dengan hasil penelitian Budiari (2014) mendapatkan persentase potongan komersial dengan urutan yang sama yaitu 16,29\%, 30,90\%, 27,81\% dan $25,01 \%$ Serta hasil penelitian hasil penelitian Nuriyasa (2012) mendapatkan persentase potongan komersial dengan urutan yang sama yaitu $15,79 \%, 31,28 \%, 26,17 \%$ dan $26,76 \%$.

Hasil penelitian pengunaan limbah wine terfermentasi sampai level $10 \%$ dalam ransum kelinci jantan lokal terhadap komposisi fisik karkas ( Daging, Tulang dan Lemak) secara statistik tidak menunjukan perbedaan yang nyata $(P>0,05)$. Cunningham dan Acker (2001) menyatakan umur ternak yang muda akan menghasilkan persentase daging dan tulang relatif tinggi dan persentase lemak rendah. Sebaliknya pada umur yang lebih tua persentase daging dan tulang akan rendah sedangkan persentase lemak akan relatif lebih tinggi,dimana pada penelitian ini ternak kelinci yang dipotong memiliki umur yang sama sehingga persentase komposisi fisik yang dihasilkan tidak menunjukan perbedaan yang nyata. Menurut Rihi (2004) peningkatan persentase karkas yang dihasilkan relatif rendah akan memberikan pengaruh yang tidak nyata terhadap persentase daging dan tulang karkasnya. 
Tabel 2. Karkas kelinci jantan local yang diberikan ransum dengan tambahan limbah wine anggur terfermentasi

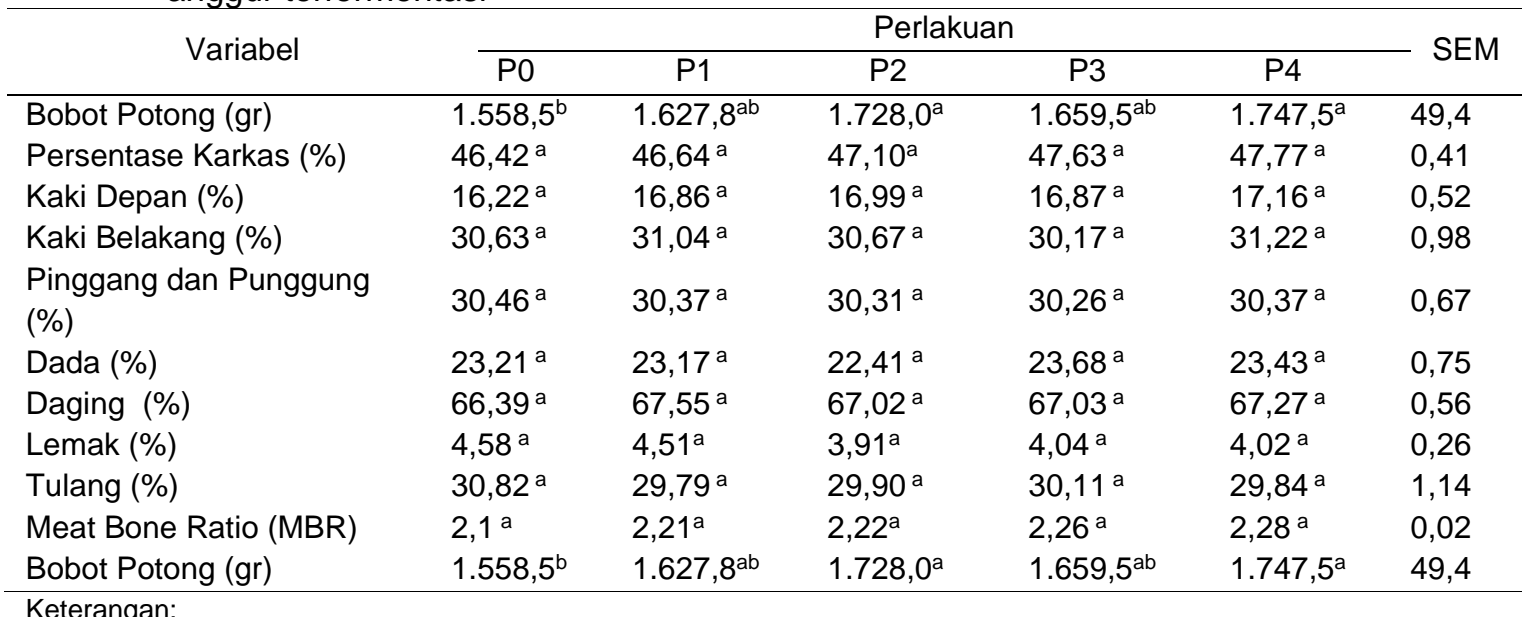

1. P0: ransum tidak menggunakan limbah wine anggur terfermentasi dan non-fermentasi (ransum control), P1 dan P2: ransum menggunakan $5 \%$ dan $10 \%$ limbah wine anggur terfermentasi serta P3 dan P4: ransum menggunakan 5 dan $10 \%$ limbah wine anggur non fermentasi

2. Superskrip yang sama pada barus yang sama menunjukkan perbedaan yang tidak nyata $(P>0,05)$ dan superskrip berbeda pada baris yang sama menunjukkan perbedaan yang nyata $(P<0,05)$

3. SEM: Standard Error of the Treatment Mean

Hasil penelitian pengunaan limbah wine terfermentasi sampai level $10 \%$ dalam ransum kelinci jantan lokal terhadap meat bone ratio secara statistik tidak menunjukan perbedaan yang nyata ( $P>0,05)$. Aberle et al. (2001) menyatakan bahwa semakin tinggi nilai meat bone ratio menunjukkan bahwa kualitas karkas semakin baik, karena meat bone ratio dapat menggambarkan tinggi rendahnya hasil daging dan tulang dari karkas. Meat bone ratio yang tinggi menunjukkan bahwa hasil daging dari karkas lebih tinggi. Hasil penelitian ini lebih rendah dibandingkan hasil yang didapat oleh Dewi et al. (2012) yang menyatakan nilai MBR kelinci jantan lokal umur 6 dan 12 Bulan berkisar antara 2,77-2,98 dan 2,83-3,04, dalam penelitian ini umur pemotongan yang berbeda yaitu lebih muda (umur 4 Bulan), sehingga bobot karkas yang dihasilkan akan lebih rendah yang berpengaruh terhadap komposisi fisik karkas, dimana pada umur muda pertumbuhan tulang dan daging hampir berimbang bila dibandingan kelinci dengan umur yang lebih tua.

\section{PENUTUP}

Berdasarkan hasil penelitian diatas maka dapat disimpulkan bahwa pengunaan limbah wine anggur non fermentasi dan terfermentasi dalam ransum sampai level $10 \%$ tidak menyebabkan perbedaan performa dan karkas kelinci jantan lokal.

\section{DAFTAR PUSTAKA}

Abarghuei, M. J., Y. Rouzbehan and D. Alipour. (2010). The influence of the grape pomace on the ruminal parameters of sheep. Livestock Science, 132, 73-79.

Alhaidary, A., H.E. Mohamed and A.C. Beynen. (2010). Impact of Dietary Fat Type and Amount on Growth Performance and Serum Cholesterol in Rabbits. American J. of Animal and Veterinary Sciences 5(1): 60-64.

Aberle, E. D., C. J. Forest, H. B. Hedrick, M. D. Judge dan R.A. Merkel. (2001). 
The Principle of Meat Science. W.H. Freeman and Co. San Fransisco.

Basuki, P., (2002). Dasar Ilmu Ternak Potong dan Kerja. Bahan Ajar. Fakultas Peternakan Universitas Gadjah Mada. Yogyakarta.

BPS. (2013). Produksi Buah Anggur di Kabupeten buleleng. Badan Pusat Statistik Kabupeten Buleleng. (serial online) [cited 2015 Jul 8]. Available from: http:/www.buleleng.bps.go.id.

Bram Brahmantiyo dan Y.C. Raharjo. (2009). Pengembangan Pembibitan Kelinci Di Pedesaan dalam Menunjang Potensi dan Prospek Agribisnis Kelinci. Seminar Nasional Teknologi Peternakan dan Verteriner. Balai Penelitian Ternak, Bogor. Hal 688691.

Cunningham, M., and D. Acker. (2001). Animal Science and Industry. $6^{\text {th }}$ edition. Prentice Hall. New Jersey

Dewi, S.H.C., Edi, P.,M. Djalil. (2012). Produksi karkas dan non karkas kelinci lokal pada umur dan jenis kelamin berbeda. (prosiding): Membangun ketahanan pangan berbasis kearifan lokal untuk menopang perekonomian rakyat. Yogyakarta,12 September 2012. Seminar nasional Fakultas Agro Industri, Universitas Mercu Buana.

Dwiyanto, K., R. Sunarlin and P. Sitorus. (1985). Pengaruh Persilangan terhadap Karkas dan Preferensi Daging Kelinci Panggang. J. IImu dan Peternakan. 1(10):427-430

Ensminger, M.E., J.E. Oldfield and W. Heinemann. (1990). Feed Nutrition. $2^{\text {nd }}$ Ed, the Ensminger Publishing Co., Clovis.

Hartadi, H., Kustantinah, Zuprizal, E. Indarto, N.D. Dono., (2008). Nutrisi dan Pakan Ternak. Fakultas Peternakan Universitas Gadjah Mada. Yogyakarta.

Lukefahr, S.D., W.D. Hohenboken, P.R. Cheeke, N.M. Patton and W.H. Kennick. (1981). Carcass and Meat Characteristics of Plemish Giant and New Zealand White Purebreed and Terminal - Crossbred Rabbits. J. Of Appl, Res. 4(3): 66-72.

Mastika, I.M. (1991). Potensi Limbah Pertanian dan Industri Pertanian serta
Pemanfaatannya untuk Makanan Ternak. Makalah Pengukuhan Guru Besar Ilmu Makanan Ternak Pada Fakultas Peternakan UNUDDenpasar.

McNitt, J.I., N.M. Nephi, S.D. Lukefarh and P.R.Cheeke. (1996). Rabbit production. Interstate Publishers, Inc.p. 78-109

Moote, P., J. Church, K. SchwartzkopfGenswein, and Van Hamme. (2012). Effect of fermented winery waste supplemented rations on beef cattle temperament, feed intake, growth performance and meat quality. Submitted Article, Kamloops, BC, Canada: Thompson Rivers University.

NRC. (2001). Nutrient Requirement of Rabbits. National Academy of Sciences, Washington, D.C

Nugroho, H. (1982). Beternak Kelinci Secara Modern. Penerbit Eka Offset, Semarang.

Nuriyasa, M. (2012). "Respon Biologi Serta Pendugaan Kebutuhan Energi dan Protein Ternak Kelinci Kondisi Lingkungan berbeda $\mathrm{Di}$ Daerah Dataran Rendah Tropis"(disertasi). Program Pasca Sarjana. Universitas Udayana. Denpasar.

Parakkasi, A., (1999). IImu Nutrisi dan Makanan Ternak Ruminansia. UI Press. Jakarta.

Rasyaf, M. (1996). Beternak Ayam Pedaging. Penebar Swadaya. Jakarta.

Rihi, J.L. (2004). Produksi karkas dan kualitas fisik daging kelinci lokal yang diberi kosentrat dengan level protein berbeda. Buletin Peternakan 28 (2): 65-71

Sartika, T. and Y.C. Raharjo. (1991). Pengaruh Berbagai Tingkat Serat Kasar Terhadap Penampilan, Persentase Karkas pada Kelinci Rex. (prosiding). Seminar Nasional Usaha Peningkatan Peternakan dan Perikanan. Vol. 1. Bidang Peternakan. Badan Penerbit Univ. Diponogoro, Semarang.

Siregar, S., (1994). Ransum Ternak Ruminansia. Penebar Swadaya. Jakarta. 
Soeparno. (2005). Ilmu dan Teknologi Daging. Cetakan ke-4. Gadjah Mada University Press, Yogyakarta.

Steel, R.G.D. and J.H.Torrie. (1991) .Principle and Procedure of Statictic.McGrow Hill Book Bo.Inc,New York.

Suradi, K. (2005). Potensi dan peluang Teknologi Pengolahan Produk Kelinci. (prosiding) Lokakarya Nasional Potensi dan Peluang Pengembangan Usaha Kelinci. Pusat Penelitian dan pengembangan Peternakan.Badan penelitian dan pengembangan Pertanian dan Fakultas Peternakan Universitas Padjadjaran. Bandung 30 September 2005

Voisinet, B. D., T. Grandin, J.D. Tatum, S.F. O'Connor and J.J. Struthers. (1997). Feedlot cattle with calm temperaments have higher average daily gains than cattle with excitable temperaments. Journal of Animal Science, 75, 892896. 